makes multiple tracer studies more complicated."

In reply to their query the method used to measure the loss of potassium from the dialysate, which was $150 \mathrm{mEq}$ in my series ${ }^{1}$, was a direct measurement. The statement by them that: "there is a wide range of potassium status in patients with chronic renal failure being maintained with haemodialysis" contradicts their next statement that: "The absence of a positive relation between the duration of regular dialysis trearment and the total body potassium, together with the balance studies in two patients, indicates that twice-weekly dialysis against a dialysate potassium content of $1 \mathrm{mEq} / 1$. is compatible with the maintenance of potassium balance." This conclusion is reached from two patients only.

Finally, I would like to reiterate a statement in my paper" that "a level of $1 \mathrm{mEq} /$ litre in the dialysate fluid may be too low" for use in prolonged haemodialysis and suggest that this level should be adjusted according to various factors such as dietary intake of potassium; variation in potassium states found among non-dialysed patients with chronic renal failure as suggested by Boddy et al.; duration of prolonged haemodialysis; and the type of dialyser and the number of hours necessary for patients to be dialysed per week.-I am, etc.,

Department of Medicine,

Y. K. SEEDAT University of Natel

1 Seedat, Y. K., British Medical fournal, 1969, 2

2 Veall, N., and Vetter, H., Radioisotope Techniques in Clinical Research and
London, Butterworth, 1958.

\section{Urinary pH and Excretion of Gentamicin}

SIR,-Gentamicin is excreted mostly through the kidneys. ${ }^{2}$ Since it is a weak base its renal clearance might be expected to be non-ionic diffusion across the tubular epithelium, and so vary according to urinary pH. So far as we know, the excretion of gentamicin in relation to urinary $\mathrm{pH}$ has not previously been investigated, and we therefore decided to measure simultaneously the renal and venous (total) clearances of gentamicin and inulin (as a reference) in three healthy men volunteers, aged 31-36, after acid and alkali loading.

After a priming dose of inulin $50 \mathrm{mg} / \mathrm{kg}$ and gentamicin $0.4 \mathrm{mg} / \mathrm{kg}$, inulin and gentamicin in isotonic saline (after acid load) or isotonic sodium bicarbonate (alkali load) were intravenously infused continuously at the rate of $30 \mathrm{mg} / \mathrm{min}$ (inulin) and $0.2 \mathrm{mg} / \mathrm{min}$ (gentamicin). Clearances were measured twice in each subject-firstly, after oral administration of ammonium chloride $15 \mathrm{~g}$ and, secondly, under an intravenous load of sodium bicarbonate given in a primary dose of $8.4 \mathrm{~g}(\mathrm{M} / 2$ solution) and then in a sustaining dose of $8.4 \mathrm{~g}$ (M/6 solution) Samples of blood, urine, and perfusate were taken initially, and after about one hour of infusion a blood sample was taken and the bladder emptied. Exactly one hour later a furthe blood sample was taken, the bladder contents were collected directly into a measuring cylin$\mathrm{der}$, and the urine $\mathrm{pH}$ immediately measured. After a further exactly-timed period of one hour the urine was again collected and a final sample of blood taken. Renal clearance measurements, protein binding studies, and inulin and gentamicin assays were carried by standard techniques, which are not described here for sake of brevity, but which we would gladly communicate to any interested correspondent.

The results are summarized in the Table and in Figures 1 and 2. The mean urinary clearance of gentamicin was $92 \mathrm{ml} / \mathrm{min}$ after acid load and $98 \mathrm{ml} / \mathrm{min}$ after alkali load. The correlative venous clearances were 122 $\mathrm{ml} / \mathrm{min}$ and $106 \mathrm{ml} / \mathrm{min}$. The (U/P gent.) $/(\mathrm{U} / \mathrm{P}$ in.) was 0.786 in acidosis and 0.861 in alkalosis, and the ( $p / P$ gent. $) /(p / P$ in $)$ was respectively 1.078 and 0.886 . Applying Student's $t$ test to these results there is no significant difference between (U/P gent.) $\mathrm{U} / \mathrm{P}$ in.) in alkalosis and acidosis $(t=2 \cdot 54$, $P>0.05)$, whereas ( $p / P$ gent.)/( $p / P$ in.) is significantly higher in acidosis than in alkalosis $(t=2.79,0.05>\mathrm{P}>0.02)$. Protein binding was lower in alkalosis (less than $0 \cdot 10)$ than in acidosis $(0 \cdot 34)$.

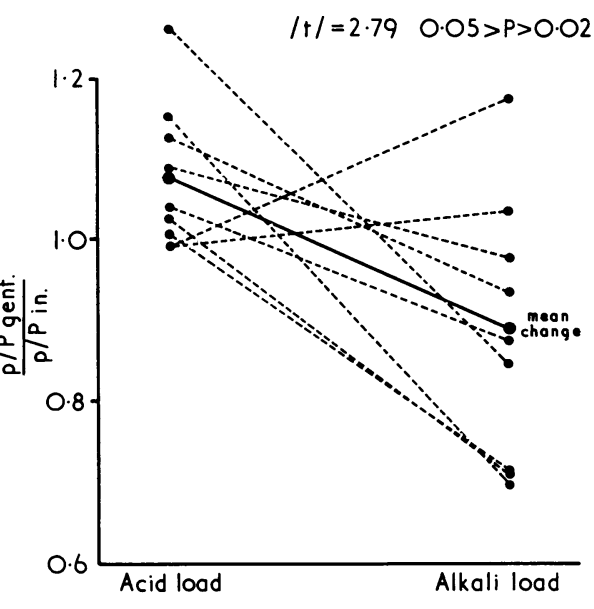

Fig. 1-Effect of acid and alkali loading on urinary Fig. 1-Effect of acid and alkali loading on uring
clearance of gentamicin with inulin as reference.

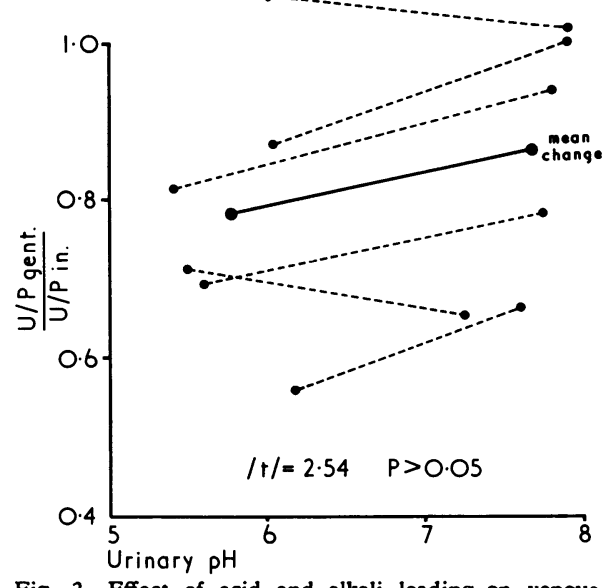

Fig. 2-Effect of acid and alkali loading on venous clearance of gentamicin with inulin as reference.

We were satisfied that tubular diffusion trapping was not a significant problem and that glomerular filtration of free gentamicin is the principal way of renal clearance of this drug. Moreover, the kidney is the principal way of total gentamicin clearance, ${ }^{3}$ and our findings show that this does not vary with changes in the urinary $\mathrm{pH}$. It is not therefore necessary to alter the dosage of gentamicin aocording to the patient's acidbase state.

We thank Laboratoire Unilabo-Schering France for a grant in support of this work Drs. C. Desroches and F. Billard, who performed the inulin assays; and Drs. C. Gaudebout and J. J. Pocidalo for advice and statistical help

-We are, etc.

MarIel

P. VEYSSIER

J-C. PeCherr

Hôpital Claude Bernard,

E. De Cerner

Clin que de Maladies Infectueuse

(Prof. A. Domart),

75 - Paris 19c.

1 Jao, R. L., Jackson, G. G., fournal of the Gingell, I C and Waterworth, P. M, Brich Medical Fournal, 1968, 2, 19. 3 Black, J. B., Calesnick, B., Williams, D., and Chemo:herapy, $1963,3,138$

- Chisholm, G. D., Calnan, J. S. Waterworth, P. M., and Reis, N. D., British Medical łournal, 1968, 2, 22.

\section{Smoking and Pregnancy}

SIR,-I was interested in the observation by Dr. John McGarry and Miss Joan Andrews (8 April, p. 74) that during pregnancy the

Comparison Between Acid and Alkali Urinary and Venous Clearances

\begin{tabular}{|c|c|c|c|c|c|c|c|c|c|c|c|c|c|c|c|}
\hline & \multicolumn{7}{|c|}{ Acid Loading } & \multicolumn{7}{|c|}{ Alkali Loading } & S \\
\hline & Cu gent & Cv gent & $\mathrm{Cu}$ in & $\mathrm{Cv}$ in & $\frac{U / P \text { gent }}{U / P \text { in }}$ & $\frac{p / P \text { gent }}{p / P \text { in }}$ & $\underset{\mathrm{pH}}{\text { Urinary }}$ & $\begin{array}{c}\text { Urinary } \\
\text { pH }\end{array}$ & $\frac{p / P \text { gent }}{p(P \text { in }}$ & $\frac{U / P \text { gent }}{U / P \text { in }}$ & $\mathrm{Cv}$ in & $\mathrm{Cu}$ in & Cv gent & Cu gent & \\
\hline 1 & $\begin{array}{l}71 \\
78\end{array}$ & 102 & $\begin{array}{l}126 \\
125\end{array}$ & 91 & $\begin{array}{l}0.561 \\
0.693\end{array}$ & $\begin{array}{l}1.028 \\
1.154 \\
1.006\end{array}$ & $\begin{array}{l}6 \cdot 18 \\
5 \cdot 60\end{array}$ & $\begin{array}{l}7 \cdot 60 \\
7 \cdot 75\end{array}$ & $\begin{array}{l}0.710 \\
0.703 \\
0.712\end{array}$ & $\begin{array}{l}0.666 \\
0.789\end{array}$ & 115 & $\begin{array}{l}112 \\
104\end{array}$ & 81 & $\begin{array}{l}75 \\
82\end{array}$ & 1.98 \\
\hline 2 & $\begin{array}{r}109 \\
99\end{array}$ & 136 & $\begin{array}{l}134 \\
139\end{array}$ & 138 & $\begin{array}{l}0.814 \\
0.716\end{array}$ & $\begin{array}{l}1.087 \\
0.998 \\
0.998\end{array}$ & $\begin{array}{l}5 \cdot 40 \\
5 \cdot 50\end{array}$ & $\begin{array}{l}7 \cdot 80 \\
7 \cdot 23\end{array}$ & $\begin{array}{l}0.976 \\
1.036 \\
1.177\end{array}$ & $\begin{array}{l}0.940 \\
0.651\end{array}$ & 128 & $\begin{array}{l}133 \\
136\end{array}$ & 135 & $\begin{array}{r}125 \\
89\end{array}$ & $2 \cdot 01$ \\
\hline 3 & $\begin{array}{r}108 \\
85\end{array}$ & 128 & $\begin{array}{r}102 \\
97\end{array}$ & 114 & $\begin{array}{l}1.057 \\
0.877\end{array}$ & $\begin{array}{l}1.259 \\
1.129 \\
1.040\end{array}$ & $\begin{array}{l}6.00 \\
6.02\end{array}$ & $\begin{array}{l}7 \cdot 88 \\
7 \cdot 88\end{array}$ & $\begin{array}{l}0.847 \\
0.932 \\
0.879\end{array}$ & $\begin{array}{l}1.120 \\
1.000\end{array}$ & 117 & $\begin{array}{l}103 \\
102\end{array}$ & 103 & $\begin{array}{l}116 \\
102\end{array}$ & 1.90 \\
\hline Mean & 92 & 122 & & & 0.786 & 1.078 & & & 0.886 & 0.861 & & & 106 & 98 & \\
\hline
\end{tabular}

S Body area

Cu Urinary clearance

Cv Venous (total) clearance

gent Gentamicin

$\begin{array}{ll}\text { in } & \text { Inulin } \\ \text { p } & \text { Prefusate concentration } \\ \text { P } & \text { Plasma concentration } \\ \text { U } & \text { Urinary concentration }\end{array}$


mean level of serum vitamin $B_{12}$ among smokers is significantly less than among non-smokers. They discuss various factors which may have affected the serum $B_{12}$ level, but they do not mention folate deficiency, which is common during pregnancy.

Low serum $B_{12}$ levels have been observed in over $40 \%$ of patients with megaloblastic anaemia due to folate deficiency, and the levels rise slowly to within the normal range on treatment with folic acid alone.12 As Dr. McGarry and Miss Andrews have not published the serum folate levels in their group of pregnant women, it is not possible to draw conclusions from the $B_{12}$ levels unless all the women were taking folic acid.-I am, etc.,

J. Forshaw

Sefton General Hosp.tal,

Liverpool

1 Mollin, D. L., Waters. A. H., and Harris, E., in Vitamin B12 and Intrinsic Factor, Europäisches Symposium, Hamburg. ed. H. C. Heinrich, p. The

Forshaw, J., and Harwood, L., fournal of Clinical
Pathology, 1971, 24, 244.

\section{Truncal Vagotomy and Pyloroplasty}

SIR.-Mr. F. I. Tovey (29 January, p. 311) is quite right in advising surgeons working in developing countries against a reversion to the old policy of gastrectomy for duodenal ulcer. In my own experience with peptic ulcer surgery among rural patients, mostly refugees from erstwhile East Pakistan resettled in this region over the past 13 years, the patients were happier after vagotomy and drainage, as they could resume their bulky diets more easily. Truncal vagotomy did not produce troublesome diarrhoea in any of our patients. The drainage procedure was to a great extent determined by the site and state of the ulcer.

According to Aird, "1 "in the 'twenties of the present century the commonest site of a duodenal ulcer submitted to operation was the anterior wall of the first part"; but he had "not since the war seen an unperforated ulcer of the antetior wall of the duodenum which could have been locally excised." $\mathrm{He}$ was "tempted to conclude that anterior wall ulcer of the duodenum is always acute, perforating before it can become chronic." In my series ${ }^{2} 56$ out of 95 duodenal ulcers, all chronic and unperforated, were situated on the anterior w-1l. This is interesting and perhaps proves that, in the natural history of duodenal ulcer, India is $40-50$ years behind Britain.

An anterior ulcer, especially with gross scarring and stenosis as seen in many of our cases, may make pyloroplasty technically difficult.-I am, etc.,

ARABinda Mitra

Tagore Hospital,

Dandaka:anya Project,

Kon 'agaon,
Madhya Pradech, India

1 Aird, I., A Companion in Surgical Studies, 2nd edn., p. 707. Edinburgh and London, Living-

Mitra, A., Indian Fournal of Surgery, 1971, 23,

Value of the M.C.V.

SIR.-Recent correspondence ${ }^{2}$ in this journal has indicated the relationship between the red cell mean corpuscular volume (M.C.V.) and mean corpuscular haemoglobin concentration (M.C.H.) when the values are

\begin{tabular}{|c|c|c|c|c|c|c|}
\hline & & 1 & 2 & 3 & 4 & 5 \\
\hline $\begin{array}{l}\text { Haemoglobin }(\mathrm{g} / 100 \mathrm{ml}) \\
\text { Haematocrit }(\%) \\
\text { M.C.V. }\left(\mu^{2}\right) \\
\text { M.C.H. }\end{array}$ & $\begin{array}{l}1 \\
2 \\
3 \\
4 \\
5\end{array}$ & $\begin{array}{l}1.00 \\
0.95 \\
0 \cdot 22 \\
0.38 \\
0.50\end{array}$ & $\begin{array}{l}1.00 \\
0.19 \\
0.23 \\
0.20\end{array}$ & $\begin{array}{l}1.00 \\
0.91 \\
0.19\end{array}$ & $\begin{array}{l}1.00 \\
0.58\end{array}$ & 1.00 \\
\hline
\end{tabular}

obtained from a Coulter Model "S" automatic counter. We have been conducting in Coventry a haematological survey using this apparatus on a random population sample of 81 male and 89 female subjects aged 65 years and over. As the correlation coefficients were homogenous $(P>0.05)$ in the two sexes, we have pooled the data (Table). Statistically we found little to choose between M.C.H. and M.C.V., which confirms our findings in other population studies where $r$ for this correlation lay between +0.89 and +0.98 .

The poor correlation of the mean corpuscular haemoglobin concentration with either the M.C.V. or M.C.H. is not surprising in view of its curious distribution, ${ }^{3}$ which adds another statistical objection to its use.-We are, etc.,

N. K. SHINTON P. C. ElwoOd

Coventry and Warwickshire Hospital,

1 Rose, M. S., British Medical foumal, 1971, 4, 169.

England, J. M., Walford, D. M., and Waters D. A.' W., British Medical Fournal, 1971, 4.232 : Elwood, P. C., British fournal of Social and
Preventive Medicine, 1964, 18, 81.

\section{Vaccination against Rubella}

SIR,-There are a few points which might, perhaps, be added to Dr. Constance A. C. Ross's comprehensive review of this subject (8 January, p. 109).

Although there is some presumptive evidence that rubella vaccine will produce a long period of immunity, perhaps lifelong, it should be emphasized that this is presumptive only and that one cannot say definitely that a girl of 12 years immunized against rubella will retain that immunity until the end of her reproductive life. In addition, natural immunity may be maintained by intermittent exposure of the immune to the natural virus, and if the epidemiology of the disease is altered radically by immunization this may prove to be a factor of some importance.

By far the most important place for the transmission of rubella infection is the primary school, and the majority of pregnant women come into contact with the disease through an infected primary school child, either directly or through an intermediate case. In spite of the theoretical advantage of protecting women in their child-bearing years against rubella by immunizing girls before they reach the reproductive age, it may be more logical to immunize children of both sexes before they attend school or kindergarten. This would produce an immune population in the group who were previously most susceptible and were the main vehicles of spread of the disease.

An advantage of this method of protection is that reactions to the vaccine are generally less in children of 4-5 years than in children of 11-14 years; this is important with regard to acceptability of the vaccine by the public. Should the duration of pro- tection of the vaccine prove to be lasting, then adults would be directly as well as indirectly protected.-I am, etc.,

J. S. DoDge

Department of Preventive and Social Medicine,

University of Otago,
Dunedin, New Zealand

\section{Pantie-girdle Syndrome}

SIR,-Recently in this department we have been seeing an increasing number of patients with symptoms ranging from tingling to swelling of the feet and legs, with or without ulceration. Sometimes they present with meralgia paraesthetica. All these patients are wearing pantie-girdles, of a new type which I personally have not seen before. Removal of the pantie-girdle very rapidly produces a "cure."

Most people unfortunately seem to buy one of a size smaller than they should, and all of course are overweight. The age range is from 20 to 70 and over. The older patients combine this pantie-girdle with knickers with elasticated bottoms. It needs little imagination to appreciate what happens to the venous return from the leg. When these patients sit up it acts as a very effective venous tourniquet, and when they cross one leg over another-which many of them have to do because of the brevity of their skirtsit acts as a partial arterial tourniquet.

There has been a lot of correspondence recently about deep vein thrombosis. Such people suffer from chronic venous stasis, and if they are admitted for emergency operation they run an increased risk of deep vein thrombosis. We in this depamtment now refer to it as the "pantie-girdle syndrome." -I am, etc.

Physical Medicine Department,

T. K. Davidson

General Hospital

\section{Inexpensive One-way Screen}

SIR,-In many hospitals the advantages of a one-way window are outweighed by the cost. Not only the price of the window itself, but also that of sound equipment has to be found. While such sophistication is both desirable and possible in a large teaching hospital this is often not the case in a small hospital for the mentally ill or handicapped. A simple but effective one-way screen can, however, be made for little cost-if there is no need for the interview room to be soundproof.

An aperture of suitable size is made in the party wall between two rooms (or even one room and a large broom cupboard). A window frame can then be fitted; it makes a neat finish but is not essential. The opening is covered by fine mesh black nvlon facing material (normally used for interfacing coat collars etc. and available from most drapers at less than $50 \mathrm{p}$ per yard). The material may be stuck down or stapled, the latter method being preferable as wire or equipment may 